Tomasz Nowicki

https://doi.org/10.26881/pwe.2021.52.06

ORCID: 0000-0002-3382-1791

Uniwersytet Gdański

tomasz.nowicki1982@wp.pl

\title{
Ludzkie zoo w percepcji dzieci
}

\section{Summary \\ Children's perception of the Human Zoo}

The presented article explores the idea of the Human Zoo and the children's perception of the possibility of keeping people in the Zoo. From the point of view of analytical practice, the collected statements of children were examined by means of a critical discourse analysis understood by Fairclough as textual and linguistic social practices reflecting the symbolic structure. The children's statements show unequivocal resistance to the vision of exposure of the human body and strong species identification. The images of the Human Zoo make it possible to see the orientation to the perception of the species relationship in the normative dimension. This orientation takes place on an emotional level, confirming research in the field of moral development and the concept of emotivism. The reversal of order, in turn, shows the social order as a brutal genre struggle, activating the imaginary of nature perceived as threatening and dangerous.

Keywords: human zoo, collecting, children, emotivism, commodification of gaze, postcolonialism

Słowa kluczowe: ludzkie zoo, kolekcjonowanie, dzieci, emotywizm, utowarowienie spojrzenia, postkolonializm

\section{Wprowadzenie}

Prezentowany artykuł porusza kwestię mało zbadaną i mało popularną w pedagogice wczesnej edukacji, dotyczącą związków kształtowania się dziecięcych relacji z tym, co pozaludzkie, relacji człowiek-zwierzę. Koncentruję uwagę na jednym wąskim aspekcie tej relacji, stanowiącej wycinek szerszych badań i analiz, które przeprowadziłem na potrzeby rozprawy doktorskiej poświęconej związkom dzieciństwa i zwierzęcości oraz edukacji dzieci w zoo. Na potrzeby niniejszej publikacji dokonałem wyboru najistotniejszych aspektów teoretycznych, historycznych i empirycznych omawianego zagadnienia, skupiając się na kwestii ludzkiego zoo i dziecięcej percepcji możliwości trzymania ludzi w zoo. Materiał empiryczny, który stanowił podstawę moich analiz, został wygenerowany podczas przeprowadzonych wywiadów z dziećmi. Badaniem były objęte dzieci w wieku 7-8 lat, uczennice i uczniowie szkoły podstawowej. Grupa stanowiła łącznie 39 osób 
uczęszczających do trzech różnych klas w tej samej szkole podstawowej. Wybór kryterium wiekowego podyktowany był ustaleniem minimalnych parametrów poznawczych i rozwojowych dzieci, pozwalających na przeprowadzenie wywiadu i uzyskanie informacji w zakresie postawionych problemów badawczych (Bee 2004). Od strony praktyki analitycznej zebrane wypowiedzi dzieci były badane za pomocą krytycznej analizy dyskursu rozumianej za Faircloughem (2001: 8-9) jako tekstowe i językowe praktyki społeczne odzwierciedlające strukturę symboliczną. Proces analizy obejmował trzy etapy: pierwszy krok dotyczył tekstów mówionych, na tym etapie rozpoznawałem tematyczną strukturę tekstów. Następnie poszukiwałem zawartych w nich procesów społecznych oraz identyfikowałem możliwości recepcji dyskursów w podmiotowości oraz wytwarzanych znaczeń (rekonstruowałem dyskurs). Teksty mówione traktowałem jako konstrukt pierwszego stopnia, tj. kategorie, którymi posługiwali się respondenci, które poprzez analizę były porządkowane w kategorie drugiego stopnia - tworzone w toku analizy (Jabłońska 2013: 56). Podczas ostatniego kroku analizy teksty umieszczano w odniesieniu do struktur, praktyk oddziaływania dyskursów oraz ich konsekwencji. Na tym etapie analiza miała charakter interdyskursywny, podczas którego wnioski odnosiłem do innych badań z obszaru problemowego.

\section{Kulturowe źródła kolekcjonowania}

W publikacji poświęconej kolekcjonowaniu The Culture of Collecting John Elsner i Roger Cardinal podkreślają, że sama idea kolekcjonowania powinna być rozumiana dużo szerzej, niż zazwyczaj stosuje się ten termin (Elsner, Cardinal (eds.) 1994). Zwracają uwagę na to, że gromadzeniu w jednym miejscu określonej grupy obiektów, połączonym z rozwojem wiedzy, towarzyszy zawieszenie porządku normatywnego. W celu wpisania w określony porządek gromadzonych $\mathrm{w}$ jednym miejscu obiektów uruchamiane zostają narzędzia etykietowania, klasyfikowania i segregacji. Badacze ci twierdzą, że do pewnego stopnia Holocaust daje się wpisać w mechanizmy towarzyszące tworzeniu kolekcji, segregacji i narzucania określonego porządku przy jednoczesnym zawieszeniu norm. W ich przekonaniu gorliwość, z jaką cywilizacja zachodnia wytwarzała swoje zbiory i kolekcje, w różnych kontekstach przybierała zbrodnicze znaczenie. Kolekcjonowaniu często towarzyszą antropologiczne operacje odbywające się w jądrze rozumienia podmiotowości, w których „czystość” obiektu jest zestawiana z „nieczystością”, „swojskość” z „obcością". Tworzenie tego pola semantycznego wiąże się z operacjami włączania i wyłączania określonych grup „obiektów”. W odniesieniu do zoo badacze zwracają uwagę na historię arki i uznanie Noego za pierwszego kolekcjonera. Noe tworzy swoją kolekcję pośpiesznie, ścigając się z czasem nadchodzącego potopu. Mimo to - jak podaje Biblia - udaje mu się stworzyć kolekcję kompletną. W biblijnej przypowieści mamy do czynienia z ratowaniem w dosłownym sensie, ratowaniem przed wyginięciem. Kolekcjonowanie staje zatem czymś więcej, zostaje przyporządkowane idei przekraczającej partykularyzmy ludzkiego 
egoizmu. Ten moment transcendencji w kontekście teologicznym umieszcza kolekcjonowanie w obszarze realizacji planu Bożego. Kolekcjonowanie obiektów zostaje umieszczone w porządku aksjologiczno-normatywnym, wykraczającym poza idee wartości samych w sobie, wartość kolekcji zależy od rozpoznania i nazwania celów oraz wpisania ich realizacji w sferę obowiązków. W przypowieści o Noem jako archetypie pierwszego kolekcjonera pojawiają się najważniejsze dla tej dyscypliny tematy, są to: pożądanie i nostalgia, ratowanie i utrata, pragnienie zbudowania trwałego i kompletnego systemu przeciwko niszczycielskiej sile przemijania. Znaczącym motywem społeczno-biopolitycznym pozostaje wizja arki Noego jako projektu powoływanego w wyniku zbliżającej się katastrofy ekologicznej. Metafora arki Noego zyskuje na popularności w XVII w., kiedy to powstają wyspecjalizowane sklepy nawiązujące do pierwszej kolekcji. Otwarty w Paryżu popularny sklep z egzotycznymi przedmiotami nosi nazwę „Arka Noego” (Elsner, Cardinal (eds.) 1994: 12). Nawiązania do mitu o Noem odnajdujemy także w gabinecie osobliwości „Arka” Johna Tradescanta oraz dziełach Athanasiusa Kirchera, Georga Horna, którzy tytułują swoje prace „,arka Noego” (Elsner, Cardinal (eds.) 1994: 174). Ogrody zoologiczne do dzisiaj zachowały terminologię ugruntowaną w czasach kolonialnych, opisując trzymane w zoo zwierzęta mianem kolekcji.

Z kolei Hanna Schreiber zwraca uwagę na to, że pojęcie osobliwości konotuje takie pojęcia, jak rzadkość i niezwykłość. Łacińskie znaczenia mirabilis ('przedziwny, godny podziwu, cudowny') oraz mirari ('dziwić się, przyglądać się, podziwiać') mają wspólny rdzeń mir. Tym samym celem kolekcji mirabiliów jest „odzwierciedlenie” (ang. mirror) świata, w którym Bóg zajmuje centralne miejsce (Schreiber 2012: 100). W przypadku ogrodów zoologicznych tę kosmologię będą tworzyć transpozycje: nominalnego z ogólnym, dzikiego ze sztucznym, naturalnego z nienaturalnym, ziemi i krwi.

\section{Ludzkie kolekcje „inności”}

Fascynacja tym, co obce i inne, wzrasta w czasach kolonialnych. Kolekcjonowanie obiektów z Nowego Świata ujawnia znaczenie polityczne takich pojęć, jak: rzadkość, wartość i osobliwość - ewoluujących na przestrzeni XVI-XVIII w. (por. Kieniewicz 2003: 184196). Gabinety osobliwości stają się w drugiej połowie XVI w. ważną gałęzią przemysłu sztuki „prymitywnej”. Ich liczebność będzie liczona w setkach prywatnych i publicznych kolekcji (Pomian 2001: 73). Pod koniec XVIII w. kolekcjonowanie się instytucjonalizuje. Nagromadzenie bogactw przywożonych z podbijanych kolonii uzyskuje poziom nasycenia, który pozwala na zestawianie i porównywanie przedmiotów, umożliwiając ich klasyfikację i hierarchizację. Pionierskie w tym zakresie są wyprawy pod dowództwem kapitana Jamesa Cooka, który w latach 1768-1779 zwozi do Anglii liczne okazy roślin i zwierząt oraz opowieści o napotkanej ludności tubylczej. Wyprawy Cooka szybko zyskują zainteresowanie badaczy i elit intelektualnych Zachodu. Hasło „gabinet historii naturalnej" zostaje wpisane do Encyklopedii Diderota, w której wyjaśnia się, że tworzenie 
wiedzy z zakresu nauk przyrodniczych jest możliwe dzięki posiadaniu odpowiedniego zbioru obiektów naturalnych (Jaques 1997: 193).

Wkrótce we Francji powstaje pierwsze w historii Towarzystwo Badaczy Człowieka, w którego skład wejdą filozofowie, lekarze, historycy, biolodzy i podróżnicy. Celem Towarzystwa będzie interdyscyplinarne badanie fizycznych, moralnych i intelektualnych aspektów nauki o człowieku (Jahoda 2007: 19). Członkowie stowarzyszenia będą postulować, aby badacze, którzy biorą udział w wyprawach poza kontynent europejski, przywozili z nich żywy materiał badawczy, najlepiej w postaci przedstawicieli obu płci, w różnym wieku czy też większych próbek badawczych w postaci całych rodzin. Postulują też konieczność pozyskiwania nieżywych obiektów, dostrzegając w nich szansę na możliwość dalszych badań oraz preparacji zwłok, które można następnie umieścić w muzeum (Jaques 1997: 193). W końcu system wytwarzanej wiedzy odnajdzie epistemologiczną matrycę, która pozwoli osiągnąć kompletność w prowadzonych badaniach - laboratoria te przybiorą osobliwą postać wiedzy i rozrywki, połączą ciekawość spojrzenia na to, co inne, z ciekawością poznawczą, zostaną stworzone ludzkie ogrody zoologiczne (Jaques 1997: 194). Pojęcie rasy będzie szeroko rozwijane w dziewiętnastowiecznej literaturze uzasadniającej różnicę i wyższość rasy białej wobec „ras kolorowych”. Największą popularność zyska w tym kontekście praca Arthura de Gobineau Szkice o nierówności ras ludzkich.

Przedstawiciele ludności podbijanych kolonii i zdobycze z wypraw najpierw staną się żywym inwentarzem i własnością kolekcji mecenasów i sponsorów wypraw kolonialnych - arystokracji i monarchów. Będą spełniać funkcję estetyczną i użytkową - ludność ta nadawała egzotycznego kolorytu dworom oraz świadczyła przymusową pracę (Earle, Lowe (eds.) 2005: 155). Na dworach epoki renesansu istniały wielkie ludzkie menażerie, których posiadanie stanowiło świadectwo dobrego tonu i kosmopolityzmu. Niemniej dopiero XIX w. przyniesie rozwój instytucji muzeum oraz pawilonów prezentujących dziedzictwa narodowe, będące ornamentem ekonomicznej dominacji i postępu. Wystawy te cieszyły się ogromnym zainteresowaniem zwiedzających: londyńska wystawa przyciągnęła 6 milionów osób w 1851 r., paryska 16 milionów w 1878 r. i 50 milionów w 1900. Wspólnym spoiwem wszystkich wymienionych wystaw jest imperializm, nacjonalizm, społeczny darwinizm oraz utowarowienie spojrzenia (Schreiber 2012: 146). Walter Benjamin (2005) ten rodzaj doświadczenia nazwie „miejscami fetyszyzmu towarowego”, które łącząc w sobie materialność transakcji ekonomicznej i symbolicznej, stwarzały poczucie tożsamości narodowej. Ukoronowaniem przemian społeczno-kulturowych stanie się ludzkie zoo, które jako maszyna antropologiczna umacnia supremację rasową, narodową oraz gatunkową.

Ogrody z ludźmi nazywano także wioskami tubylczymi, w których na zaaranżowanej scenie pokazywano przedstawicieli homo sapiens sapiens odgrywających scenki rodzajowe, takie jak np. tańce rytualne. Pierwszą zorganizowaną dla szerokiej publiczności ludzką ekspozycją była wystawa paryska, na której na szeroką skalę zaaranżowano wioski, na których tle zaprezentowano 400 tubylców z kolonii francuskich (Corbey 1993: 341). Ludzkie ekspozycje przyciągnęły uwagę publiczności, stając się od razu hitem 
światowych wystaw. Prężnie rozwijały się firmy wyspecjalizowane w organizacji ludzkich zoo, które oprócz wiosek tubylczych potrafiły zaaranżować ,egzotyczne ulice”, tańce rytualne, polowania, pokazy jazdy konnej. Nie zawsze formy ekspozycji ludzi przybierały formę inscenizacji odmiennych cech czy zachowań, autorzy tworzyli też ekspozycje hybrydowe, łącząc pokazy ludzkich zwierząt z nieludzkimi zwierzętami. W zależności od koncepcji wystawy realizowane były różne warianty nadawania znaczeń: różnicy i kontinuum między białym Europejczykiem, zwierzęciem, płcią a człowiekiem prymitywnym. Na wystawach można było obejrzeć dzikie i okrutne Amazonki wyobrażone jako erotycznie wyzwolone i piękne kobiety z ludu Samoa, czy też Indian, w których widziano romantyczne ucieleśnienie więzi z naturą. Ludzkie menażerie miały charakter spektaklu, miały wydobywać i produkować różnicę, służyły uwydatnianiu supremacji białej rasy. Wystawy ludności z podbijanych przez europejskie mocarstwa terytoriów, podobnie jak w przypadku zwierząt, przybierały postać kilku przewijających się toposów, takich jak: historia powstawania człowieka, supremacja białej rasy, oddawanie poddańczego hołdu władzom kolonialnym, mit dzikiego Zachodu, mit kanibala (Corbey 1993: 167). Podkreślając różnicę przez budowanie opozycji cywilizowani - dzicy, zwierzęcy - ludzcy, wystawy te wzmacniały kulturowe mity o raju utraconym, grzechu pierworodnym, różnicy rasowej. $Z$ jednej strony spotkania $\mathrm{z}$ egzotycznym Innym miały być pokazem pogardy i wyższości, z drugiej zaś wkomponowywały się w romantyczny resentyment tęsknoty za utraconym stanem natury.

Zoo wzbogacone o ludzkie kolekcje było świetnie rozwijającym się komercyjnie interesem. Oprócz samych pokazów, które przyciągały tysiące zwiedzających, produkowano także pamiątkowe pocztówki ze zdjęciami podbitych ludów. Pocztówki przykuwały uwagę publiczności i służyły także jako nośnik reklamy mającej przyciągnąć do wystaw kolejnych zwiedzających. Sukces finansowy, jaki przynosiło to przedsięwzięcie, pozwalał na utrzymanie ogrodów zoologicznych, które organizowały specjalne pokazy poświęcone jedynie prezentacji ludzkiego inwentarza. Pośród twórców, którzy wypromowali swoje nazwisko i pozycję na organizowaniu ludzkich zoo, należy wymienić prekursora wielkich pokazów ludów Carla Hagenbecka. Jego berlińskie pokazy potrafiły w ciągu jednego dnia przyciągnąc 58 tysięcy widzów, z kolei w Paryżu szacuje się, że na zorganizowaną przez niemieckiego wystawcę ekspozycję w ciągu stu dni przybyły 2 miliony zwiedzających. W samych Niemczech w latach 1875-1900 odbyło się ponad sto takich wystaw, na których prezentowano grupy od 3 do 250 osób naraz. Paryskie zoo w latach 1877-1912 zorganizowało ponad trzydzieści pokazów ludów tubylczych, które każdorazowo podwajały przychody ogrodu zoologicznego. Ludzkie kolekcje prezentowano także w Wielkiej Brytanii, Holandii, Austrii, Stanach Zjednoczonych czy też w Polsce (Pawlik 2008: 38).

Ludzkie ciała sprowadzone do ogrodów zoologicznych były łatwym i pożądanym obiektem zainteresowań ówczesnych uczonych. Badacze mieli przywilej kontaktu i dostępu do ludzkich menażerii przed publicznością, indywidualne badania pozwalały na prowadzenie niezakłóconej obserwacji. Dzięki ludzkim menażeriom powrócono do badań nad osobliwością, badania antropologiczne stanowiły swoistą grę poszukiwania i wyjaś- 
niania różnicy i podobieństwa. W owym czasie nie widziano sprzeczności i trudności metodologicznej pomiędzy łączeniem komercyjnej rozrywki z obserwacją naukową. Środowiska naukowe popierały idee ludzkich menażerii, argumentując, że przyczyniają się one do rozwoju nauki. Możliwość prowadzenia badań w tak skonstruowanych warunkach poznawczych sprzyjała rozwojowi takich dyscyplin, jak: antropometria, frenologia, fizjonomika i kraniologia.

Sama idea ekspozycji zwierząt w wymiarze biopolitycznym i ekonomicznym ściśle wiązała się z zachodzącymi zmianami w sposobie kawałkowania populacji, wytwarzania podmiotowości oraz kapitalizowania ludzkiego ciała jako środka biopolitycznej produkcji. Ludzkie ciało umieszczone w porządku zarządzanym przez ekonomię spojrzenia miało ukazywać cielesność jako część systemu polityczno-gospodarczego, w którym życie w swojej cielesnej afektywnej formie podlegało subsumpcji pod kapitał (zob. Hardt, Negri 2012: 511-522). Związanie samego ciała z jego afektywnością w legalny i akceptowalny porządek ekonomiczny pozwalało na wytwarzanie wartości dystrybutywnej płci, rasy, gatunku, klasy oraz okresu życia stanu przedludzkiego (dzieciństwa). System gospodarczy oparty na kolonializmie mógł reifikować ciała wyjęte spod porządku administracyjnego i moralnego. Tworzone były w ten sposób miejsca inkluzji ciała zalegalizowanego do realizacji pracy biopolitycznej oraz ciała naznaczone społecznym stygmatem pracy wykonywanej na ciele, takie jak żebractwo czy też praca seksualna. W ten sposób nowy porządek gospodarczy wytwarzał podmiotowości, w których stopień subsumpcji życia, ciała pod kapitał był jednocześnie porządkiem dystrybucji człowieczeństwa. Im bardziej stopniowalne były relacje upodmiotowienia, rozumianego jako podleganie pod różne warstwy porządków społecznych, tym większy był przychód wynikający z mobilności kategorii dystrybuujących człowieczeństwo ciała pod kapitał. Przy czym należy podkreślić, że ludzkie zoo pomimo bezpośredniego związku z kolonializmem należy odróżnić od praktyk niewolnictwa, które wykorzystywały pracę ludów kolonizowanych do produkcji innych dóbr. We wstawieniu ludzkiego ciała w system ekonomii i redystrybucji spojrzenia relacja wykorzystania ludzkiej pracy na rzecz kapitału została przeniesiona z produkcji materialnej w obszar tego, co w operaizmie nazywane jest pracą niematerialną, czyli kapitalizowaniem samej cielesności i jej afektów. W produkcji niematerialnej samo działanie staje się wytworem pracy i zyskiem kapitału, różnica czy też relacja między pracą produkującą jakieś dobro zostaje zniesiona, czyniąc samo działające ciało wytworem w tym sensie używam pojęcia pracy biopolitycznej do ludzkiego zoo. Produktem staje się samo życie rozumiane jako zdolność do reagowania z otoczeniem, responsywność ciała na wzrok i wytwarzana w ten sposób relacja pedagogiczna stają się źródłem wytwarzania podmiotowości i tego, jak należy rozumieć cielesność (Bednarek 2012: 241). Przez pedagogiczność tej relacji rozumiem potencjał socjalizacyjny wytwarzanych w ten sposób sposobów patrzenia. Konstruowana w warunkach zoo ekonomia spojrzenia pozwala zrozumieć interpasywny (zoo ma być praktykowane, a nie rozumiane) wymiar interpelowania się określonych norm społecznych, warunków poznania jako obiektywnych i naturalnych. Przykład ludzkiego zoo jest w tym kontekście bezpośrednią egzemplifikacją tego, 
że w relacji spojrzenia pomiędzy odwiedzającymi zoo zwierzętami a zwierzętami znajdującymi się w ekspozycji doświadczenie różnicy pozycji jest jedynie doświadczeniem stopnia i granicy upodmiotowienia rozumianego jako różne modus porządku społecznego. Doświadczenie różnicy jest w tym kontekście przypadkowe i historyczne (wytwarzane prawdy moralne są przypadkowe).

\section{Zoo z ludźmi - wyniki badań}

W przeprowadzonym badaniu jedno z pytań podczas prowadzonych wywiadów z dziećmi brzmiało: „Wyobraź sobie, że w zoo trzyma się ludzi? Co by się stało?”. Pytanie o kwestię trzymania i wystawiania ludzi miało charakter otwarty, który miał pozwolić dzieciom na uruchomienie swobodnych skojarzeń i wypowiedzi. Zależało mi na tym, aby nie sugerować dzieciom w tym pytaniu odwołania do wiedzy, faktów czy też porządków normatywnych, estetycznych itp. Zakładałem, że pytanie otwarte stworzy większą szansę kodowania kategorii pojęciowych, które może uruchomić potrzeba wyobrażenia zoologizacji ludzkiego życia. Kody wyłonione w procesie analizy przedstawiono w tabeli 1. Przyjęta struktura prezentująca matrycę analizy danych empirycznych wynika bezpośrednio z orientacji metodologicznej krytycznej analizy dyskursu (KAD) i jest efektem denaturalizacji tekstów mówionych oraz funkcji ideologicznych, kluczowych do określenia pozycji podmiotowych zidentyfikowanych w dyskursie (Szkudlarek 1997: 184).

Tabela 1. Zoo z ludźmi

\begin{tabular}{|l|l|l|}
\hline $\begin{array}{c}\text { Przyjmowane pozycje } \\
\text { wobec koncepcji } \\
\text { ludzkiego zoo }\end{array}$ & Zmienność w obrębie kategorii & \multicolumn{1}{|c|}{ Numery wywiadów } \\
\hline \multirow{5}{*}{ Emocje } & $\begin{array}{l}\text { Dziwny/śmieszny/niemądry } \\
\text { pomysł }\end{array}$ & $\begin{array}{l}2,3,4,7,8,9,10,13,23,24,32, \\
38(12 \text { wywiadów) }\end{array}$ \\
\cline { 2 - 3 } & Wywołuje smutek & $4,17,22,28,30,34$ (6 wywiadów) \\
\cline { 2 - 3 } & Nie byłoby ciekawe, byłoby nudne & 5,10 \\
\cline { 2 - 3 } Moralność & Ludzie zwariowaliby & 22 \\
\cline { 2 - 3 } & Razem & $\mathbf{1 8}$ wywiadów \\
\hline & $\begin{array}{l}\text { Pozycja etyczna - chciałbym } \\
\text { otworzyć klatkę/ nie poszłabym } \\
\text { do takiego zoo; Trzeba uwolnić } \\
\text { ludzi i wprowadzić zwierzęta - } \\
\text { przywrócenie porządku }\end{array}$ & $\begin{array}{l}7,8,9,12,16,20,24,26,37,38 \\
(10 \text { wywiadów) }\end{array}$ \\
\cline { 2 - 3 } & $\begin{array}{l}\text { Nie powinno się trzymać ludzi } \\
\text { w klatkach ani dorosłych zwierząt }\end{array}$ & 15 \\
\cline { 2 - 3 } & Razem & $\mathbf{1 1}$ wywiadów \\
\hline
\end{tabular}




\begin{tabular}{|c|c|c|}
\hline \begin{tabular}{|c|} 
Przyjmowane pozycje \\
wobec koncepcji \\
ludzkiego zoo
\end{tabular} & Zmienność w obrębie kategorii & Numery wywiadów \\
\hline \multirow{10}{*}{ Odwrócenie porządku } & $\begin{array}{l}\text { Ludzie czuliby się, jak zwierzęta } \\
\text { w zamknięciu }\end{array}$ & $6,22,23,27,36$ (5 wywiadów) \\
\hline & $\begin{array}{l}\text { Ludzie zostaliby zjedzeni przez } \\
\text { zwierzęta/ zwierzęta zabiłyby ludzi }\end{array}$ & $6,16,18,19$ (4 wywiady) \\
\hline & $\begin{array}{l}\text { Zwierzęta kierowałyby zoo/ } \\
\text { zajęłyby pozycję ludzi (inny } \\
\text { świat - w znaczeniu porządek 33) }\end{array}$ & $13,23,33$ (3 wywiady) \\
\hline & Ludzie umrą z głodu, nie jedliby & 24,29 \\
\hline & $\begin{array}{l}\text { Ludzie zaczęliby polować na } \\
\text { zwierzęta, zwierzęta by wyginęły }\end{array}$ & 11 \\
\hline & Koniec cywilizacji & 35 \\
\hline & Świat zmieniłby się w horror & 25 \\
\hline & Zwierzęta byłyby wkurzone & 34 \\
\hline & $\begin{array}{l}\text { Zwierzęta chciałyby być na } \\
\text { wolności }\end{array}$ & 21 \\
\hline & Razem & 17 wywiadów \\
\hline \multirow[b]{2}{*}{$\begin{array}{l}\text { Inne } \\
\text { (niezaklasyfikowane) }\end{array}$} & $\begin{array}{l}\text { Inni - niż biali - ludzie byli kiedyś } \\
\text { w zoo }\end{array}$ & 1 \\
\hline & $\begin{array}{l}\text { Ludzie lubią zoo i lubią trzymać } \\
\text { tam nie ludzi, ale zwierzęta } \\
\text { (ludzi można oglądać w innych } \\
\text { miejscach) }\end{array}$ & 14 \\
\hline
\end{tabular}

Źródło: opracowanie własne.

Jedną z pierwszych rzeczy, która ujawniła się w większości wypowiedzi respondentów, było potraktowanie koncepcji zoo w perspektywie trzymania i prezentowania ludzi jako więzienia i zniewolenia. Zarówno na planie emocjonalnym, normatywnym, jak i moralnym możliwość stworzenia ludzkiej menażerii kojarzono jednoznacznie negatywnie. W przypadku planu emocjonalnego 18 respondentów z badanej grupy dzieci artykułowało wypowiedzi o charakterze emocjonalnym, nazywając pomysł ludzkiego zoo dziwnym, śmiesznym i niemądrym (12 wywiadów), wskazywano też na to, że sytuacja, w której to ludzie znajdują się w klatkach, wywoływałaby smutek (6 wywiadów):

- Jakbyś miała wyobrazić sobie taki eksperyment, że w zoo trzyma się ludzi. Co wtedy by się stało? Patrzysz i oglądasz?

- To by było trochę dziwne

- Czemu? Chodzilabyś oglądać?

- Tak, ale nie cieszyłabym się wtedy (wywiad 4). 
- Jakbyś miał sobie wyobrazić, że idziesz do zoo i w klatkach zamknięci są ludzie. Co by się wtedy stało?

- Byłoby mi smutno (wywiad 28).

Jeśli chodzi o sądy moralne deklarowane przez respondentów w reakcji na pomysł trzymania w zoo ludzi, były one jednoznacznie kontrfaktualne wobec antycypowanej koncepcji. Sądy moralne odwołujące się do powrotu poprzedniego porządku artykułowało 11 uczestników badań:

- Jakbyś miał sobie wyobrazić, że idziesz do zoo i w klatkach zamknięci są ludzie. Co by się wtedy stało?

- Byłbym zdziwiony. To zwierzęta powinny być w zoo, a nie ludzie.

- Czemu ludzie nie powinni być w zoo?

- Nie wiem. Oglądaliby jakby swój gatunek w zoo. To by było dziwne (wywiad 38).

Odnośnie do porządku społecznego 17 rozmówców widziało w koncepcji ludzkiego zoo zburzenie dotychczasowej hierarchii, postrzegając zawartą w pytaniu możliwość jako dystopię społeczną:

- Jakbyś mial sobie wyobrazić, że idziesz do zoo i w klatkach zamknięci są ludzie. Co by się wtedy stało?

- Świat zamieniłby się w jakiś horror (wywiad 25).

Wobec planu emocjonalnego ujawniał się on na trzech płaszczyznach: moralnej, estetycznej i epistemologicznej. Wizja ekspozycji ludzkiego ciała wywoływała smutek:

- Jakbyś miał sobie wyobrazić, że idziesz do zoo i w klatkach zamknięci są ludzie?

- Byłbym smutny.

- Chodzilbyś do takiego zoo?

- Nie, bym nie chodził.

- A czemu byś był smutny?

- Bo jest dużo ludzi i byłoby ich mniej (wywiad 17).

Smutek pojawiał się w kontekście reakcji na zawartą w pytaniu możliwość istnienia ludzkiego zoo. Wydaje się więc właściwe umieszczanie interpretacji tak skonstruowanego pytania także w perspektywie relacyjnej. Emocje jako wyznacznik moralności w kontekście artykułowania sądów moralnych w teorii etycznej nazywane są emotywizmem. Emotywizm zakłada istnienie zależności pomiędzy naszą kondycją biologiczną, gatunkową a przyznaniem każdej ludzkiej istocie wartości. Według Lazari-Pawłowskiej (1980: 199-219) emotywizm nie próbuje uzasadnić potrzeby etyki skoncentrowanej na człowieku, ale stara się ją wyjaśnić. Emotywizm zakłada, że nie wszystkie rozstrzygnięcia moralne dają się sprowadzić do logicznych racji. Jednak mimo to jesteśmy przekonani 
co do ich słuszności, a ich przeciwieństwo budzi nasz sprzeciw. Taki mechanizm zdaje się być uchwycony w moich badaniach. Dzieci, pomimo że nie umieją uzasadnić swoich ocen, potrafią w oparciu o pojawiające się w kontekście pytania emocje wyartykułować sąd normatywny wobec ich stosunku do ludzkiego zoo. Pytanie o możliwość trzymania ludzi tak jak zwierząt w zoo zdaje się implicite ujawniać stopień identyfikacji i pokrewieństwa gatunkowego dzieci. W przypadku omawianego pytania o zoo kontekst normatywny i moralny ma charakter deskryptywny, tzn. odwołując się do stadiów rozwoju moralnego Kohlberga, należy go traktować jako efekt procesu transmisji norm społecznych i uznania autorytetu. Emotywizm zakłada, że nasze najgłębsze przekonania moralne nie wchodzą w przestrzeń logicznych uzasadnień, lecz są jedynie naszymi aksjologicznymi aksjomatami. Takim moralnym niewymagającym uzasadnienia aksjomatem może być wartość życia każdej ludzkiej jednostki. Nie jest to wybór logiczny, lecz jest to psychologiczny akt afirmacji ukształtowanych w nas uczuć moralnych. Niemniej należy pokreślić, że zaproponowane ramy interpretacyjne wyczerpują przestrzeń interpretacji w punkcie, w którym dochodzi do wzajemnego wyjaśniania źródeł, z których wyprowadzane są wnioski o charakterze normatywnym. W przypadku emotywizmu jest to uznanie źródła pochodzenia emocji z naszej struktury biologicznej i odrzucenia ich społeczno-kulturowego charakteru. W przypadku teorii rozwoju moralnego jest to stwierdzenie pochodzenia treści zasad moralnych z transmisji kulturowej i socjalizacji. To, co istotne w obu ramach interpretacyjnych, dotyczy uznania deskryptywnego, zdeterminowanego adaptacyjnie podejścia do kształtowania się postaw moralnych. W przedmiotowym badaniu w reakcjach emocjonalnych dzieci ujawnia się silna identyfikacja gatunkowa, dzieci socjalizują poczucie odmienności biologicznej względem zwierząt, identyfikują możliwość wejścia w relację zoologiczną w oparciu o posiadaną już ekonomię spojrzenia:

Bo ludzie lubią zoo i żeby trzymać tam nie ludzi, tylko zwierzęta, żeby podziwiać nie ludzi, tylko zwierzęta, których nie można zobaczyć na podwórku, w jakimś parku czy na meczu i w innych miejscach (wywiad 14).

Zaproponowane ujęcie stara się wyjaśnić na poziomie fenomenologicznym, dlaczego regulatorem naszych postaw moralnych może być analiza danych empirycznych. Emotywizm proponuje potraktować moralność jak psychologiczny fakt, który można opisać oraz w wyniku swojej faktyczności nie wymaga uzasadnienia. Mając to na uwadze, za zasadne należy przyjąć, że przedmiotowe badania i ich wyniki są typowe dla zaproponowanej przez Kohlberga gradacji rozwoju moralnego oraz umieszczenie przedmiotowych wypowiedzi na poziomie przedkonwencjonalnym.

Kolejnym typem wypowiedzi były te, które zaproponowany w pytaniu eksperyment myślowy opisywały w kategoriach estetycznych i hedonistycznych, odwołując się do smaku i doświadczenia, jakim byłoby oglądanie ludzi w ramach ekspozycji, którą oferuje zoo. W tych wypowiedziach mocno ujawnia się postrzeganie roli zoo w kategoriach miejsca, które rozbudza ciekawość i dostarcza rozrywki: 
- A jakbyś miała sobie wyobrazić, że idziesz do zoo i zamiast fok, lwów, zebr w klatkach umieszczeni są jacyś ludzie i patrzysz na ludzi. Co by się stało?

- Byłoby to dziwne i trochę by mi się nudziło, bo ja zawsze widzę ludzi, codziennie, a niektórych rodzajów zwierząt nie (wywiad 10).

W kontekście opozycji nudne - ciekawe objawia się ekonomiczny wymiar patrzenia na eksponowane ciała, które powinny wzbudzać zainteresowanie. Nieobecność rasy i koloru skóry w wypowiedziach ujawnia z kolei pracę wyobraźni na zestawianiu relacji człowiek zwierzę w oparciu o różnicę gatunkową. To, co szczególnie obecne w tak postawionych pytaniach, to różnicujący, graniczny i dystynktywny prymat kategorii jako obszarów rozłącznych. Smak staje się w tym znaczeniu zarówno pojęciem normatywizującym - etycznym, jak i estetycznym. Podobnie jak w przypadku uczucia smutku, to doświadczenie emocjonalne zostaje odniesione do porządku symbolicznego, w jakim dotychczas funkcjonowało dziecko. Mamy zatem ponownie do czynienia z emotywizmem, tym razem wzbudzonym uczuciem nudy, na którego podstawie wypowiadany jest sąd estetyczny.

Najbardziej reprezentowaną reakcją na zadane pytanie były zwroty określające ludzkie zoo jako pomysł dziwny, śmieszny i niemądry. Zaliczam te wypowiedzi do kodów o charakterze emocjonalnym, ponieważ ich funkcją było wyrażenie zdziwienia, uczucia dyskomfortu poznawczego oraz niechęci:

- Jakbyś miał sobie wyobrazić, że idziesz do zoo i w klatkach zamknięci są ludzie? Co by się wtedy stało?

- Byłoby dziwnie, gdyby zwierzęta kierowały zoo.

- Ludzie byliby zadowoleni?

- Chyba nie, bo czuliby się tak jak zwierzęta.

- Czyli jak?

- W zamknięciu (wywiad 23).

Mowa tutaj zatem o planie emocjonalnym o charakterze epistemologicznym. Wyrażenie „dziwny” zgodnie z definicją słownika języka polskiego oznacza 'odznaczający się czymś osobliwym i niezrozumiałym'. W możliwości odwrócenia porządku i zmiany kategorialnej charakteryzują się kognitywne możliwości umysłu. Niemożliwość wyrażoną jako niezgoda na ujrzenie swojej pozycji podmiotowej w charakterze osobliwości można rozumieć jako ekspresję głęboko socjalizowanej identyfikacji gatunkowej. Ponadto pozostałe wyrażenia wskazują też na identyfikację nie tylko na poziomie tożsamościowym, lecz także teleologicznym. Rozumiem to w ten sposób, że możliwość zobaczenia człowieka jako przedmiotu wizyty w zoo narusza wyobrażenia o zadaniach gatunkowych. Zoo posiada głęboko zakorzenioną antropologicznie funkcję społeczną i socjalizacyjną. Kształtuje relacje i zadania gatunkowe, nadając im określone cele i zadania. W tym sensie każda propozycja naruszająca strukturę semiotyczną tego miejsca zaburza także poszczególne teleologiczne części poszczególnych elementów tej struktury i matrycy poznawczej. Innymi słowy, możliwość zmiany bądź odwrócenia porządków redystrybucji ekonomii 
spojrzenia nie tyle jest niemożliwa, ile przekreśla semantyczną funkcję pojęć, które nabywamy w toku socjalizacji. Oto przykład wypowiedzi ukazującej zdziwienie oraz przekonanie, że ludzi raczej nie prezentowano w zoo:

- Jakbyś mial sobie wyobrazić, że w zoo trzyma się ludzi, to co by się stało?

- Z tymi ludźmi?

- W ogóle w takiej sytuacji. Idziesz do zoo i zamiast zwierząt patrzysz i uczysz się o ludziach.

- Na pewno największe uczucie, jakie odczułbym, to zdziwienie. A to by były takie klatki jak dla zwierząt?

- Mogłyby być klatki.

- Trochę dziwnie by to wyglądało.

- Myślisz, że tak mogło być albo że tak było kiedyś?

-Raczej nie, raczej nie było (wywiad 3).

Widać to było także w wypowiedziach wskazujących na śmieszność możliwości trzymania ludzi w zoo, która służy ekspresji różnicy oczekiwań dzieci wobec zoo i ma ukazać niepoważność takiej możliwości.

W przypadku wypowiedzi stanowiących artykulację pozycji etycznej wypowiadane przez dzieci sądy charakteryzowała potrzeba przywrócenia porządku - sprawiedliwości naprawczej. W tym przypadku zburzenie porządku nie było kojarzone z jego odrzuceniem, ale koniecznością podtrzymania ładu symbolicznego. Równie często artykulacjom sądów wzywających do przywrócenia porządku towarzyszyła postawa rezygnacji - bojkotu instytucji, która zniewalałaby człowieka. Można uznać tak wyartykułowaną postawę za charakterystyczną dla kultury judeochrześcijańskiej, w której zasady moralne zostały ufundowane na wyrażeniach opisujących postawę moralną jako ascezę, powstrzymania się od działania, wyrażeniach zaczynających się od partykuły „nie”. Należy podkreślić, że wyrażane sądy odmowy uczestnictwa i przywrócenia porządku funkcjonowały równocześnie. Zawartą w tym pozorna aporię można wyjaśnić na polu psychologii społecznej tezą o modularności sądów moralnych. Teza ta zakłada, że jednostka dysponuje wieloma kodami etycznymi. Kody etyczne nie są używane równocześnie, lecz alternatywnie w zależności od kontekstu, który aktywizuje określone dyspozycje (Wojciszke, Baryła 2000: 395-421).

Kolejną istotną grupą kodów zebraną wokół odpowiedzi dotyczących ludzkiego zoo były wypowiedzi dotyczące odwrócenia porządku społecznego. W tej odsłonie pytane o ludzkie zoo dzieci odpowiadały na postawioną w pytaniu możliwość. Toposy, które przywoływała możliwość ujrzenia w zoo ludzi, były jednoznacznie dystopiczne. Były to motywy: niebezpiecznych zwierząt, zezwierzęcenia ludzi, antropomorfizacji zwierząt. Wyłaniające się z tych wyobrażeń obrazy charakteryzowały się specyficzną formą personifikacji zwierząt, którą należy uznać za jeden ze sposobów antropomorfizacji. Specyfika tych form spojrzenia na pozycję zwierząt charakteryzowała się potraktowaniem zastąpienia pozycji ludzkiej przez zwierzęta, które stałyby się ludźmi, zachowywały i żyły jak 
ludzie. O ile zazwyczaj pojęć tych używa się do opisu metaforycznego, który ma wyjaśniać zachowania zwierząt poprzez ludzkie dyspozycje oraz nałożyć na opis biologiczny ciał zwierzęcych porównania do ludzkich ciał, o tyle w przypadku opisów zoo z ludźmi respondenci wychodzili z przestrzeni metafory, traktując transpozycję znanych porządków jako całkowite fizyczne zastąpienie:

Inny świat by nadchodził. Zwierzęta to ludzie (wywiad 33).

Można zatem mówić o antropomorfizacji całkowitej, czyli takiej, z jaką mieliśmy do czynienia w przeszłości, kiedy to zwierzętom wytaczano procesy i oskarżono o kontakt $z$ diabłem lub magię. Niemniej najbardziej adekwatnym terminem, oddającym rozumienie dziecięcych wizji ludzkiego zoo, jest postrzegane odwrócenie porządku jako metamorfozy. Nie chodzi tutaj o przemianę jako wytwarzanie nowej tożsamości, przemiany osobowości, lecz przemiany fizyczne. Najbliższy kulturowo obraz rozumienia takiego typu przemiany znamy z opowiadania Franza Kafki Przemiana (2013), w którym główny bohater, nie przestając być psychicznie człowiekiem, przybiera postać owada. Oczywiście w tym kontekście nie mam na myśli tego, że respondenci traktowali metamorfozę w kategoriach przejścia ludzkiej jaźni w zwierzęcą. Mam raczej na myśli transpozycję pozycji przy braku naruszenia porządku struktury zoo, dochodzi tu jedynie do przemieszczenia pozycji przy jednoczesnym utrzymaniu antropocentrycznej struktury. Odwrócenie porządku jest w tym zakresie tylko pozorne. Mamy do czynienia z obrazami zwierzęcych ludzi i ludzi - zwierząt:

- Wyobraź sobie, że w zoo trzyma się ludzi. Co by wtedy było?

- Dziwnie. Dziecko w łóżeczku, a na dole człowiek sobie siedzi. Nie wie, co ma zrobić. Dziwne.

- Albo tylko niektórzy byliby zamknięci, a niektórzy by ich oglądali.

- Dziwne.

- Czemu?

- No bo to jest dziwne, gdy zwierzęta chodzą sobie po ulicy, chodzą na lody, kiedy ludzie siedzą sobie w klatkach. Dziwnie to by wyglądało (wywiad 13).

Opisywane wizje odwrócenia porządku wydają się głęboko zakorzenione w naszych kulturowych i popkulturowych obrazach buntu i zemsty zwierząt. Można tutaj chociażby przywołać obraz zoo z kultowej serii filmów o Planecie Malp, w której w jednej z ostatnich wznowień serii, w obrazie z 2011 r., mamy taką scenę: małpa o imieniu Cezar wydostaje się z klatki w zoo i przebywa w nocy na terenie wybiegu. Cezar przemierza przestrzeń wybiegu, przyjmując wyprostowaną pozycję, podobną do pozycji ludzkiej - w jakiej poruszają się ludzie. W kolejnych ujęciach widzimy, że małpa zostaje zauważona przez pracowników zoo. Jeden z pracowników podchodzi z paralizatorem do Cezara i wydaje mu polecenie powrotu do klatki. Ten wyraźnie nie zamierza go wykonać. Zostaje użyty para- 
lizator. Cezar chwyta w pewnym momencie narzędzie, którym jest okładany, i wykrzykuje w języku angielskim słowo: „Nie”. Scena ta jest przełomowym punktem w dramaturgii filmu, od której zaczyna się bunt małp. W zaproponowanej w filmie wizji buntu zwierząt mamy podobny do dziecięcych interpretacji obraz transpozycji zwierzęcej, która zaczyna poruszać się jak człowiek i mówi ludzkim językiem. W dalszych odsłonach obrazu jest przedstawiona dystopiczna wizja świata, pozycja ludzi i małp przypomina walkę etniczną, w której zwalczające się plemiona dążą do wzajemnej eksterminacji. W wersji Planety Matp z 1968 r. także ukazano wizję ludzkiego zoo zarządzanego przez małpy. W scenie z ludzkim zoo odczłowieczeni ludzie próbują nawiązać kontakt z małpami. W obu przytoczonych scenach różnica gatunkowa jest jedynie różnicą usytuowania spojrzenia. W przypadku transpozycji ludzkiej pozycji mamy do czynienia z rewersem opisanej metamorfozy, ludzie stają się zwierzętami, z tą różnicą, że zmiana pozycji ludzkiej silnie pracowała z obrazem przemocy, zezwierzęcenia i walki ludzi ze zwierzętami:

- Jakbyś miała wyobrazić sobie, że w zoo trzyma się ludzi. Co wtedy by się stało? Jakby ktoś trzymal ciebie albo kogoś stąd w zoo?

- Tak jak zwierzęta, wszyscy by się pozabijali. Nie byłoby domów, bo wszyscy byliby w klatkach.

- A jakby tylko niektórzy ludzie byli zamknięci w zoo, tak jak zwierzęta?

- Nie wiem (wywiad 6).

Ostatnią istotną zmienną, jaką generowała propozycja pomyślenia umieszczenia ludzi w zoo, dotyczyła wyobrażeń dzieci odnoszących się do natury zwierząt. Wizja ludzkiego zoo kojarzyła się z bezpośrednim zagrożeniem dla życia ludzi, przywoływała obraz agresywnych, drapieżnych i niebezpiecznych zwierząt:

- Zwierzęta pozabijałyby ludzi.

- Dlaczego?

- Bo są groźne (wywiad 18).

Przekonanie o tym, że zwierzęta stanowią zagrożenie dla człowieka, jest jednym z najlepiej utrwalonych kodów ujawniających się w większości wywiadów, które prowadziłem z dziećmi. Połowa badanych wskazywała na cechy zwierząt, posługując się dyskursem zagrożenia i bezpieczeństwa. Respondenci wskazywali na związek pomiędzy odbiorem zwierząt jako niebezpiecznych a umieszczonymi obok wiwariów ostrzeżeniami. Obrazy, które wywołały konieczność dokonywania transpozycji podmiotowej ludzi i zwierząt, uruchamiały wyobrażenia zwierzęcej natury jako ujarzmionej bestii gotowej do ataku, kiedy tylko dojdzie do zburzenia porządku i przekroczenia granicy dzielącej gatunki. 


\section{Zakończenie}

Wprowadzone do polskiej pedagogiki przez Zbigniewa Kwiecińskiego (2004: 83-104) pojęcie dyskursywnego „zera” pozwala lepiej zrozumieć, czym dla tożsamości zoo jest (nie)pamięć o umieszczeniu ludzi w pozycji zwierząt. Poprzez pojęcie dyskursywnego zera należy rozumieć pominięcia, nieciągłości, przemilczenia dyskursu, które pomimo, a może właśnie dzięki swojej nieobecności pozwalają na niezakłócone działanie struktury dyskursu. Ta część struktury dyskursu ujawniała się w moich badaniach jako niemożliwość trzymania ludzi w zoo oraz pewność, że tak nie mogłoby być. Możliwość istnienia ludzkich zoo przybierała w moich badaniach postać wyparcia, w którym domykanie znaczenia, definicji, celu i misji zoo było niejako „złapane na gorącym uczynku” ukrywania. W wypowiedziach dzieci możliwość trzymania ludzi w zoo była określona jako doświadczenie wręcz horroru. Przemilczenia w tym zakresie nie mają związku z nierozliczonym kolonializmem, niewolnictwem i rasizmem czy też ich społecznym przepracowaniem, lecz stanowią wyparty punkt odniesienia. W obszarze tego przemilczenia ogród zoologiczny staje się dyskursywnie możliwy przez przedefiniowanie swoich politycznych zadań (edukacyjnych, ekologicznych) oraz behawioralne praktykowanie tego, co nie powinno być rozumiane i doświadczane jako oczywiste i naturalne. Ten praktykowany wymiar dyskursu zoo można opisać jako redystrybucję ekonomii spojrzenia i subsumpcję życia, które należy rozumieć jako wewnętrzną (nieustannie powtarzaną) pracę dyskursu.

Podsumowując, różnica gatunkowa w zaproponowanym eksperymencie pomyślenia ludzkiego zoo jest relacją pozycji, a nie substancjalną. Pozycje podmiotowe w tym eksperymencie przypominają gotowe do obsadzenia miejsca pracy niematerialnej i symbolicznej. Mimo to wypowiedzi dzieci ukazują jednoznaczny opór przeciwko wizji ekspozycji ludzkiego ciała, identyfikując przynależność gatunkową jako matrycę podmiotową (ontologiczną). Obrazy ludzkiego zoo pozwalają zobaczyć silną orientację na postrzeganie relacji gatunkowej w wymiarze normatywnym, przy czym orientacja ta odbywa się na poziomie emocjonalnym, potwierdzając badania z zakresu rozwoju moralnego oraz koncepcji emotywizmu. Odwrócenie porządku ukazuje z kolei ład społeczny jako brutalną walkę gatunkową, uruchamiając imaginarium natury postrzeganej jako groźnej i niebezpiecznej. Na koniec należy zwrócić uwagę na to, co było nieobecne w wyobrażeniach dzieci. Pomimo że pytanie dotyczyło patrzenia przez ludzi na ludzi w zoo, większość otrzymywanych wypowiedzi miała wymiar dystopiczny, dotyczyła upadku dotychczasowego porządku i zastąpienia pozycji człowieka dominacją zwierząt. Wyobrażenia ludzkiego zoo zdominował obraz i wybór walki gatunkowej.

\section{Literatura}

Bednarek J. (2012), Praca biopolityczna i nowy sktad klasowy. „Praktyka Teoretyczna”, 5. Bee H. (2004), Psychologia rozwoju człowieka. Poznań, Zysk i S-ka. Benjamin W. (2005), Pasaże. Kraków, Wydawnictwo Literackie. 
Corbey R. (1993), Ethnographic showcases, 1870-1930. „Cultural Anthropology”, 8(3).

Earle T.F., Lowe K.J.P. (eds.) (2005), Black Africans in Renaissance Europe. Cambridge, Cambridge University Press.

Elsner J., Cardinal R. (eds.) (1994), The Culture of Collecting. London, Reaction Books.

Fairclough N. (2001), Language and power. Edinburgh, Longman.

Hardt M., Negri A. (2012), Rzecz-pospolita. Poza własność prywatna i dobro publiczne. Kraków, Korporacja Ha!art.

Jabłońska B. (2013), Krytyczna analiza dyskursu w świetle założeń socjologii fenomenologicznej (dylematy teoretyczno-metodologiczne). „Przegląd Socjologii Jakościowej”, 9(1).

Jahoda G. (2007), A History of Social Psychology. From Eighteenth-Century Enlightenment to the second World War. Cambridge, Cambridge University Press.

Jaques T.C. (1997), From Savages and Barbarians to Primitives: Africa, Social Typologies and History in Eighteenth-Century French Philosophy. „History and Theory”, 36(2).

Kafka F. (2013), Przemiana. Białobrzegi, Masterlab.

Kieniewicz J. (2003), Wprowadzenie do historii cywilizacji Wschodu i Zachodu. Warszawa, Dialog.

Kwieciński Z. (2004), Pedagogiczne zero: zastosowania problemowe, epistemiczne i magiczne. „Nauka”, 2.

Lazari-Pawłowska I. (1980), Kręgi ludzkiej wspólnoty. „Etyka”, 18.

Pawlik J.J. (2008), Egzotyzm - wątpliwy zachwyt odmiennością. W: P.A. Sokołowski (red.), Misje w XIX wieku. Pieniężno, Misyjne Seminarium Duchowne Księży Werbistów.

Pomian K. (2001), Zbieracze i osobliwości. Paryż-Wenecja, XVI-XVIII wiek. Lublin, Uniwersytet Marii Curie-Skłodowskiej.

Schreiber H. (2012), Koncepcja „sztuki prymitywnej”. Warszawa, Wydawnictwa Uniwersytetu Warszawskiego.

Szkudlarek T. (1997), Poststrukturalizm a metodologia pedagogiki. „Acta Universitatis Nicolai Copernici”, 13.

Wojciszke B., Baryła W. (2000), Potoczne rozumienie moralności: pięć kodów etycznych i narzędzie ich pomiaru. „Przegląd Psychologiczny”, 43(4). 